\title{
Farmer's Perception about Agroforestry Systems for Legal Reserves in the Region of São Mateus, Espírito Santo, Brazil
}

\author{
Bruna Paolinelli Reis ${ }^{1}$ (D) 0000-0001-6431-1906 \\ Sílvio Nolasco de Oliveira Neto ${ }^{1}$ (1) 0000-0003-0182-5322 \\ Tathiane Santi Sarcinelli ${ }^{2}$ (D) 0000-0002-7473-5881 \\ Sebastião Venâncio Martins ${ }^{1}$ (1) 0000-0002-4695-987X
}

\begin{abstract}
The aim of this study is to characterize the perceptions and interests of farmers related to the adoption of agroforestry systems (AFS) for restoration of Fibria Celulose S.A.s Legal Reserves (LRs), with the production of food and nontimber forest products. Twenty farmers were interviewed in the community of São Geraldo (São Mateus, Espírito Santo, Brazil), who participated in the social projects led by the company in the community. With this, it was possible to trace the profile of farmers and farms, their knowledge of environmental suitability, and interest in the adoption of AFS. Most farmers did not have information about AFS and the possibility of its use in LR. After being educated on the opportunities established in the Brazilian Forestry Law, 12 of the interviewed farmers expressed interest in adopting AFS to restore LR, considering the potential benefits to the diversification of income, water, soil, and biodiversity conservation. Finally, it was also possible to identify species of interest by farmers for AFS composition in LRs.
\end{abstract}

Keywords: environmental adaptation, forest code, sustainable agroforestry.

\section{INTRODUCTION AND OBJECTIVES}

The Brazilian Forest Law, Law No. 12.651, of May 25, 2012, also known as the Brazil's Forest Code, presents new guidelines for the restoration of Permanent Preservation Areas (PPA) and Legal Reserves (LRs) devoid of vegetation, and/or those which present factors of degradation, with the aim of getting the associated ecological processes to function properly. In addition to the role of conservation, unlike PPAs, RLs can also have the production function, allowing the sustainable economic use of natural resources through sustainable management, provided that a low environmental impact activity is characterized and previously approved by a competent environmental agency (Martins \& Ranieri, 2014).

Under conditions in which LR rehabilitation is necessary, planting of tree species can be implemented, primarily of regional occurrence, and exotic (fruit-bearing, ornamental or for industrial purposes), which may be grown in an interim system or in consortium with an agricultural species, constituting AFS. In these cases, legislation holds that exotic species are to be used in a maximum of $50 \%$ of the area to be rehabilitated (Brasil, 2012).

Successional agroforestry systems (SAFs) are defined by the Ministry of the Environment (MMA), through Normative Instruction no. 5, of September 8, 2009, as,

soil use and occupation systems in which perennial woody plants are managed, in association with herbaceous, shrub, tree, agricultural, and forage crops, in the same management unit, according to the spatial and temporal arrangement, with high diversity of species and interactions among these components. (Brasil, 2009)

Among the different models of AFS, the so-called Agroforestry System Regenerative and Analog (AFSRA), also known as Agroforest, is the one that is best-suited, with an indication of the Legislation for RL rehabilitation, given the diversity of species in its composition, which increases its potential for conservation of soil, water, and biodiversity (Oliveira Neto et al., 2012).

\footnotetext{
${ }^{1}$ Universidade Federal de Viçosa (UFV), Viçosa, MG, Brasil

${ }^{2}$ Fibria Celulose S.A., Aracruz, ES, Brasil
} 
Prior to the approval of the revision of the Brazilian Forest Law, the areas defined as LR were intended for conservation and could be exploited for commercial purposes (Martins \& Ranieri, 2014), which restricted the rural producer to obtain income. Given the new guidelines of the new Law, and the need to develop low-impact production models that focus more on environmental aspects, without compromising on economic viability, AFS appears to be a potential alternative for the LR rehabilitation (Rodrigues et al., 2007). These systems can reduce the costs of forest restoration, and at the same time, generate income from agricultural production and the sustainable use of tree species (Navas \& Silva, 2016; Vieira et al., 2009) through different products, mainly timber companies. Among the possible advantages of these systems for conservation and environmental restoration purposes are: the increase of natural regeneration of potential areas devoid of vegetation, greater potential for survival and development of planted seedlings, reduction in the cost of maintaining planting of tree species, and substitution of herbicide use to control weed competition with agricultural crops (Vieira et al., 2009).

In this scenario, Fibria Celulose S.A., a Brazilian forestry company, proposed AFS in areas close to communities associated with its Territorial Rural Development Program (PDRT). This program consists of developing socioenvironmental projects with rural producers in their cities, with the aim of promoting local rural development through the strengthening of partnerships, by supporting small and micro-scale agricultural and forestry businesses, aspiring to achieve environmental awareness, income generation, and quality of life (Fibria Celulose, 2010).

The objective of the present study is to characterize the farmer's perception and interest in the use of Agroforestry Systems for the restoration of Fibria's Legal Reserve (LR) areas, including the production of food and non-timber forest products, in São Mateus, Espírito Santo, Brazil.

\section{MATERIALS AND METHODS}

\subsection{Study site}

São Mateus belongs to the Extreme Northeastern Microregion of Espírito Santo and has the second largest territorial extension of the state, with $2,343 \mathrm{~km}^{2}$ (Incaper, 2011). It presents a predominantly flat to light undulating topography, and the soil is predominantly classified as Red Yellow Latosol, with fertility ranging from medium to low $(\mathrm{pH}$ around 5.0$)$. It has $97 \%$ of its area with declivity below $30 \%$ and floodplains (Incaper, 2011).

The climate of the city is Aw - Tropical, with dry winter, rainy season in the summer, from November to April, and dry season in the winter, from May to October (July is the driest month). The average temperature of the coldest month is above $18^{\circ} \mathrm{C}$ and the average annual rainfall is $1311 \mathrm{~mm}$, with the highest rainfall months being from October to April (Incaper, 2011; Nóbrega et al., 2008).

The municipality is part of the Mata Atlântica biome cover, with a semideciduous seasonal forest, and the ecosystems associated with the region include wetlands, marshes, mangroves, restingas, and muçunungas, the last being endemic to the North of Espírito Santo and South Bahia (Araujo et al., 2008; Saporetti et al., 2012).

A survey of the natural regeneration potential areas, in different Espírito Santo regions, revealed the low regeneration potential of the Northern region, mainly due to the great isolation of forest remnants in the anthropic landscape (Martins et al., 2014). Therefore, for São Mateus, the use of abandonment aiming natural regeneration, as a technique for forest restoration is not to adequate. In this case, techniques such as AFS, as a viable alternative, ecologically and economically, for the rehabilitation of the Legal Reserves would be a better option.

\subsection{Methodological procedures}

Among the 30 families associated with the Territorial Rural Development Program (PDRT), who live in the São Geraldo's community, 20 families (70\%) were chosen to be interviewed, by simple random sampling, assuming that that they would represent the community satisfactorily. The community is located near the Fibria Eucalyptus plantation areas in São Mateus, Espírito Santo State, according to Figure 1.

Informal and structured interviews were conducted (Gil, 2008) with 20 farmers, lending users (18) and owners (2), who wanted to participate in the study, using a form with ethnoecological principles (Albuquerque et al., 2002) and topophilia (Tuan, 1980) on the following topics: family profile (gender, age, schooling, and income of family members), characteristics of rural property (area, labor used, factors limiting production, knowledge of the farmers about environmental adequacy, according to the Brazilian Forestry Law, more specifically about PPA and LR, knowledge and interest in the implementation of Agroforestry Systems (AFS advantages and disadvantages, use and interest in AFS for LR, arboreal and agricultural species of interest). This information was granted individually by the interviewees after reading, allowing, and signing the informed consent terms, which were available for consultation in the archives of Fibria Celulose S.A. and were responsible for the implementation of the research. The study was not linked to research institutions, but followed the requirements normally adopted in research by individuals or 


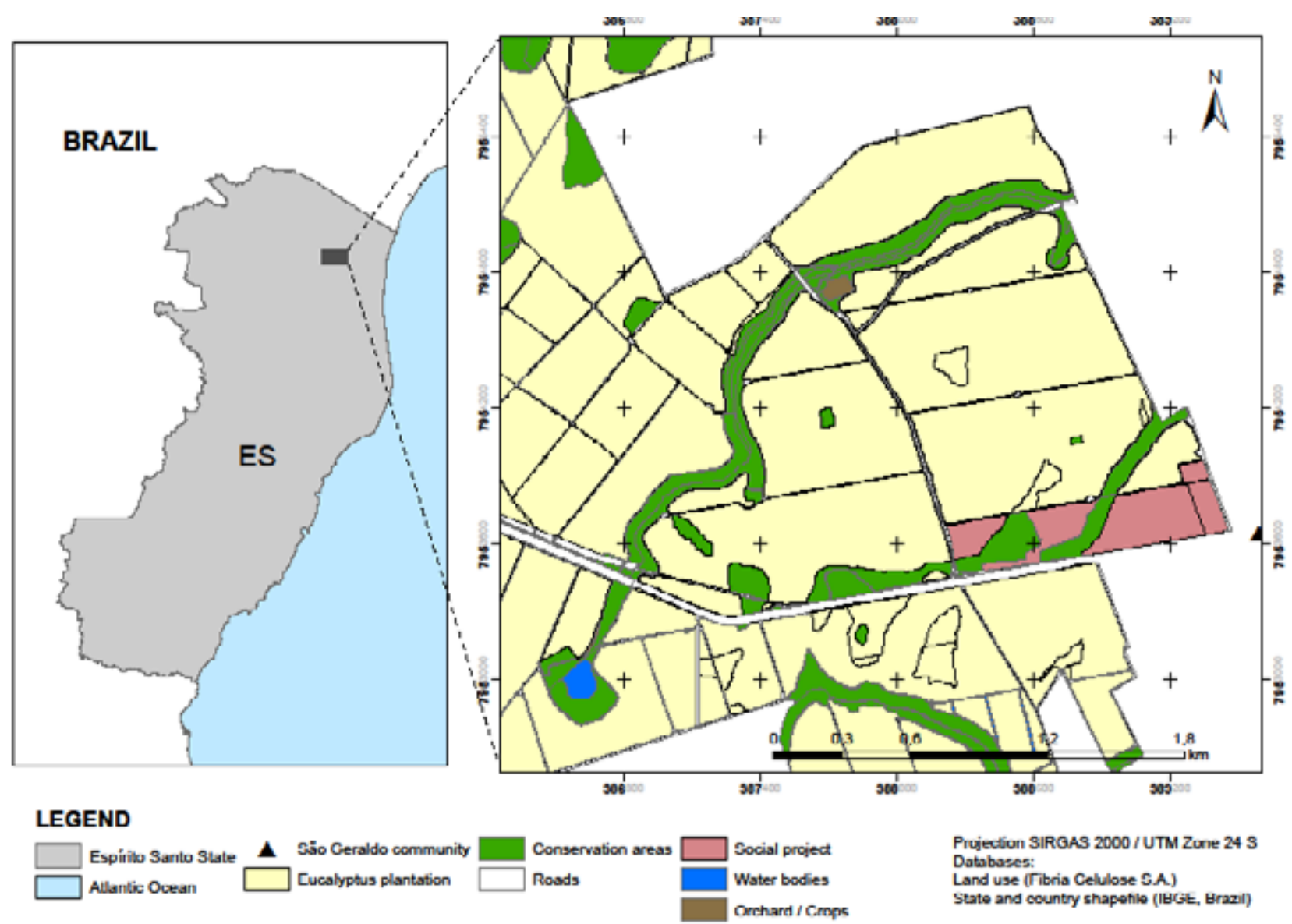

Figure 1. Map of the region where the community of São Geraldo is located, in the municipality of São Mateus, Espírito Santo State, Brazil.

groups who, by themselves and/or their legal representatives, expressed their agreement to participate in the research.

After the interviews, the data were tabulated and analyzed with the PDRT data files, allowing the elaboration of graphs and tables, and to discuss the farmer's perception and interest in AFS for LRs rehabilitation. For the identification of the arboreal and agricultural species of interest, an association was made between the common names cited by the farmers and the associated scientific names in technical and scientific literature.

\section{RESULTS AND DISCUSSION}

\subsection{Community profile}

Among the interviewees, 17 were male and three female, and only five of them had completed high school. Most families (15) had more than three members and the predominant age range of the interviewees was from 51 to 60 years. The main source of income for households was wage from labor, mostly related to agricultural enterprises in the region (agricultural technicians and agricultural machinery operators) and from agriculture (Figure 2), demonstrating the importance of agricultural crops in the livelihood of families. Most of the interviewees had a family income close to the minimum wage (Figure 3). According to Mazzon \& Kamakura (2013), the lower class in Brazil has an average monthly income of R\$ 854.00 , that is, a little less than the minimum wage.

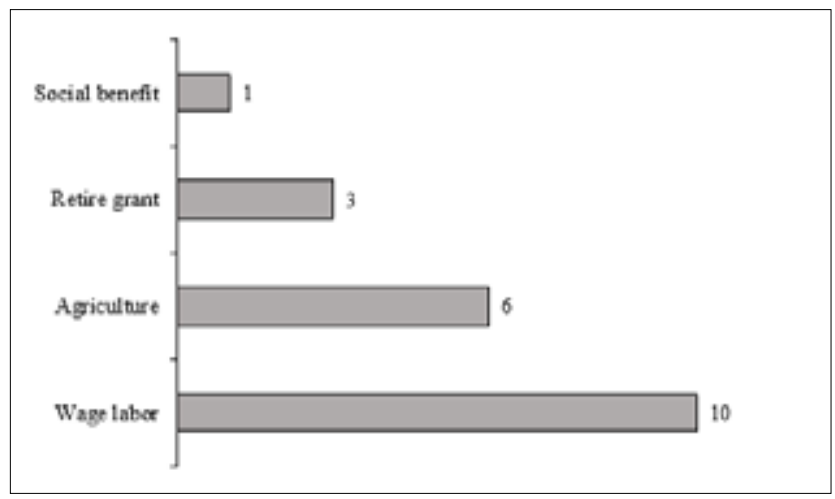

Figure 2. Main sources of income of interviewed families in São Geraldo’s community, São Mateus, ES. 


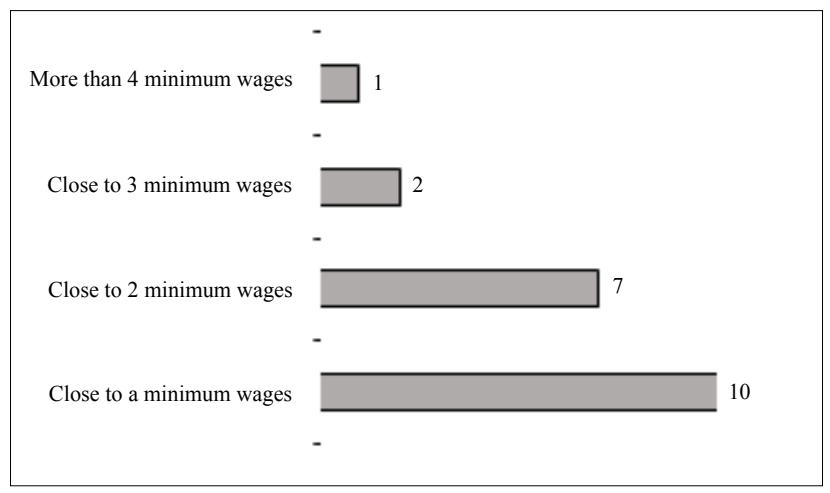

Figure 3. Monthly family income of interviewees in São Geraldo's community, in São Mateus, ES.

\subsection{Characteristics of rural properties}

Only two of the interviewees had their own area, that is, they did not use the areas assigned by Fibria (PDRT) in the form of lending, for 10 years. As 18 of the producers used the PDRT areas, they had areas between 0.5 and 1 ha, as the program offered a plot of a maximum of 1 ha. Families with their own area occupied about 10 ha.

Most interviewees (19) believe that the main limiting factor for agricultural production in the last year (2014) was the drought. However, only one respondent believes that both sandy soil and lack of rainfall had contributed to the limitation in production.

In relation to the species cultivated by the interviewees, 17 were cited, most of them being annual crops, some covering species, and short and medium cycle fruit crops. In Table 1,13 of them are listed, which are considered relevant, that is, cited on more than three occasions. In this way, the less mentioned species are cited as "Others".

Arboreal fruit species, mostly exotic, were also cited in smaller quantities. They were planted in cultivated areas or in their backyards, not mixed with the agricultural crops. This indicated that some farmers had knowledge about growing fruit trees and certain species had adapted well to local conditions. Among the species mentioned, the following stand out: orange (Citrus sinensis (L.) Osbeck), avocado (Persea americana Miller), siriguela (Spondias purpurea L.), and graviola (Annona muricata L.).

In the studied community, agricultural crops are grown both in backyards and in landscape units known as roças, the latter being predominant in the region. As reported by Quinteiro et al. (2016), small producers who use plantations and backyards usually have subsistence as their objective, that is, production is for family consumption. According to the interviewees, the main purpose of having agricultural plantations is for own consumption, and in some cases, when there is surplus in the production, for commercialization.

\subsection{Knowledge about environmental laws}

Among those interviewed, only two were owners, and thus would have had to adjust their rural properties in terms of Permanent Preservation Areas and Legal Reserves. The others, who used areas assigned to them as a lending by the

Table 1. Cultivated species and percentages of use in São Geraldo’s community, in São Mateus, ES.

Common name

\begin{tabular}{ccc}
\hline Beans & Phaseolus vulgaris L. & $15(75 \%)$ \\
Corn & Zea mays L. & $14(70 \%)$ \\
Manioc & Manihot esculenta Crantz & $13(65 \%)$ \\
Banana & Musa spp. & $10(50 \%)$ \\
\hline Pumpkin & Cucurbita spp. & $9(45 \%)$ \\
Okra & Abelmoschus esculentus L. Moench & $7(35 \%)$ \\
Potato & Solanum tuberosum L. & $4(20 \%)$ \\
Pigeon Pea & Cajanus cajan (L.) Millsp & $4(20 \%)$ \\
Watermelon & Citrullus lanatus (Thunb.) Matsum. \& Nakai & $4(20 \%)$ \\
\hline Peanut & Arachis hypogaea L. & $3(15 \%)$ \\
Cowpea beans & Vigna unguiculata (L.) Walp & $3(15 \%)$ \\
Feijão-de-porco & Canavalia esiformes (L.) DC & $3(15 \%)$ \\
\hline Achiote & Bixa orellana L. & $3(15 \%)$
\end{tabular}

*Values in parentheses refer to the percentage of farmers who mentioned the species in the interview; ${ }^{*}$ Pineaple (Ananas comosus (L.) Merril), Gherkin (Cucumis anguria L.), crotalaria (Crotalaria brevifolia DC) and black pepper (Piper nigrum L.). 
company, would not need to implement these areas, as the company had already complied with the legislation in terms of PPA and LR.

Among the respondents, only five knew the difference between PPA and LR. In addition, most of them (19) did not have information on the possibility of using Legal Reserves for producing and commercializing agricultural and forestry products. This indicates the lack of disclosure regarding changes in Legislation by the environmental agencies responsible for this in the region. This lack of knowledge could also be correlated with their need to comply with this legal requirement, in view of the lending regime to which they were submitted, as the families that owned their own area showed greater knowledge about environmental suitability.

\subsection{Knowledge on agroforestry systems}

When questioned about Agroforestry Systems (AFS), it was observed that 14 of them did not know how their structure was. In addition, all the interviewees were unaware of the possibility of using AFS for the rehabilitation of LRs.

After a brief explanation to the producers about AFS, they cited possible advantages and disadvantages of these systems. According to Figure 4, all interviewees (20) chose income diversification as the main possible benefit to be achieved with AFS, but also, to a lesser extent, mentioned possible advantages related to environmental factors, such as water, soil, and biodiversity conservation. This demonstrates that the community is also concerned about the environment, especially with the lack of water that, as previously mentioned, was considered a limiting factor to production in the prior agricultural crops.

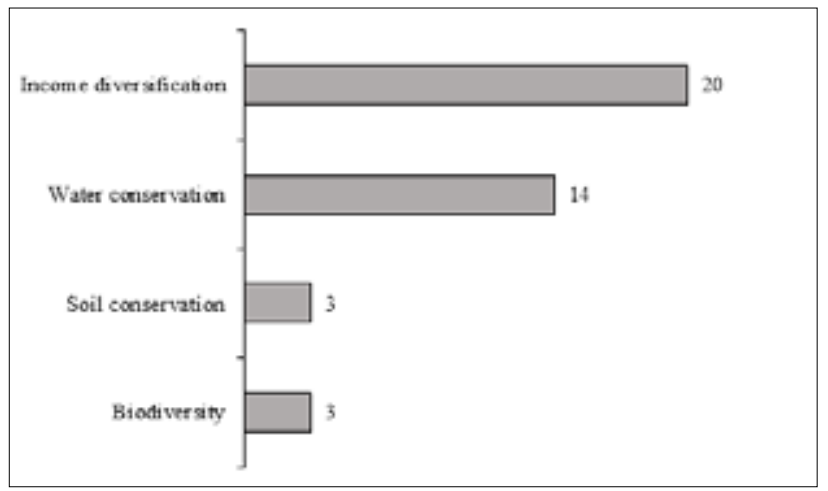

Figure 4. Perception of interviewees in the São Geraldo's community in São Mateus, ES, about the possible advantages of Agroforestry Systems.

Regarding the disadvantages of Agroforestry Systems, 15 interviewees indicated the lack of technical information, followed by the difficulty of management, including the cost of implementation. However, two of the interviewees perceived only the advantages that could be generated by AFS (Figure 5). The lack of technical information and the difficulty in handling the AFS showed insecurity about a production model that was not the usual one used in the community, suggesting the need for incentives, training, and diffusion of technology, so that producers understood the possible advantages of the system more clearly. The possible cost disadvantage may be related to the delay in the production of long cycle species, as short-cycle crops predominate among the farmers.

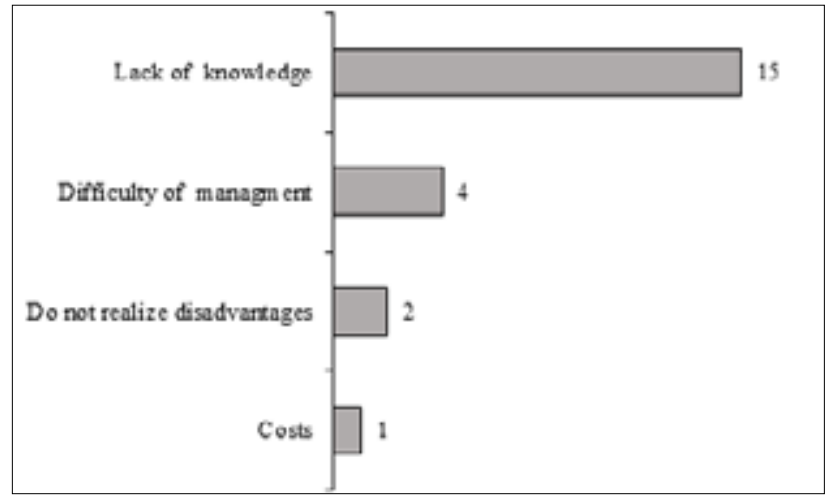

Figure 5. Perception of interviewees in the São Geraldo's community, São Mateus, Espírito Santo State, Brazil, about possible disadvantages of the Agroforestry Systems.

\subsection{Interest in agroforestry systems}

Only one of the farmers interviewed had the Agroforestry System on his property, called Agroforestry Yard, with trees and agricultural crops. As mentioned previously, the community of São Geraldo did not have sufficient knowledge about this alternative model of production, justifying the low adoption of AFS in the region.

All respondents consider that AFS is the most interesting option to recompose Legal Reserves, rather than conventional reforestation. This demonstrates that farmers perceive the possibility of producing and generating income from areas that were once considered unproductive.

When respondents were questioned about the interest in implanting AFS Fibria's Legal Reserve areas, 12 interviewees showed interest, as this would imply expandin g their planting areas. On the other hand, eight interviewees showed no interest. One of the factors that justified the lack of interest was that the workforce was only their family, often being only one farmer responsible for conducting the plantations; and increasing planting areas would generate a work overload. 
Another factor identified was the lack of knowledge about AFS, which generated insecurity in farmers who grew monoculture.

The use of adapted tree and agricultural species in the region and of farmer's interest was an essential condition for the sustainability of AFS. As most of the interviewees (12) showed interest in the implementation of AFS, they were asked to suggest agricultural species of interest for this purpose (Table 2).

Among the 14 agricultural species suggested by farmers, nine are described in Table 2, which are considered most significant, as they are cited on at least three occasions. Most requested species (maize, beans, cassava, and banana) are also the most planted today by the interviewees, which means that these are cultures that would adapt well to the local conditions, considering the experience of the producers in planting these species. These species can be strategic to the composition of the system by aiming at their greater dissemination by the use of AFS.

According to the respondents, the purpose of agricultural crops would be for their own consumption and the surplus would be for commercialization, just as it is done in the areas of conventional plantations.

Regarding AFS composition, the interest and the knowledge of the producers on planting and commercializing products of arboreal species were also evaluated. Although there is interest in a majority of those interviewed for planting tree species, many of them are not well-informed about this topic. It should be noted that the main purpose of planting these species was for production of fruits and seeds, aiming at the consumption and marketing of surplus production, and in some cases, environmental conservation.
Table 3 shows the tree species that have been suggested by the producers for use in AFS for LR rehabilitation. Of the 20 tree species suggested, 14 are described in Table 3, as only the relevant species have been considered, that is, those that have more than two citations during the interviews. The species mentioned only once are considered as "others". Only seven species mentioned by the interviewees belong to the Atlantic Forest biome (Brazilian guava, Brazilian peppertree, Yellow mombin, Cashew, Mangaba, Pitanga, and Achiote). In addition, achiote is the only arboreal species suggested by the interviewees for the composition of AFS, which is already cultivated by some farmers in the community.

As mentioned, the definition through participatory choice of species may be important for the success of AFS, especially regarding their adoption. In this case, as the proposal refers to LR areas, it must also comply with the specifications of the Brazilian Forestry Law or the new Forest Code. However, these specifications are not yet adequately clear with regard to the issue of alien species, which require attention and understanding with the environmental agencies, through the presentation of specific management plans.

\section{CONCLUSIONS}

Most farmers do not have enough information on Agroforestry Systems and the possibility of its use in areas of Legal Reserves. Two of the reasons identified were the lack of dissemination of the updates in the Forestry Law by the environmental agencies responsible for this and also by the farmers' insecurity on using a production model that is not usual in the community.

Table 2. Agricultural species of interest for the implementation of agroforestry systems for the recovery of Legal Reserve.

\begin{tabular}{|c|c|c|}
\hline Common name & Scientific Name & Number of respondents * \\
\hline Corn & Zea mays L. & $14(70 \%)$ \\
\hline Beans & Phaseolus vulgaris $\mathrm{L}$. & $13(65 \%)$ \\
\hline Banana & Musa spp. & $11(55 \%)$ \\
\hline Manioc & Manihot esculenta Crantz & $11(55 \%)$ \\
\hline Watermelon & Citrullus lanatus (Thunb.) Matsum. \& Nakai & $11(55 \%)$ \\
\hline Pumpkin & Cucurbita spp. & $6(30 \%)$ \\
\hline Organic Fertilizers ${ }^{\star *}$ & - & $4(20 \%)$ \\
\hline Potato & Solanum tuberosum L. & $4(20 \%)$ \\
\hline Pineapple & Ananas comosus (L.) Merril & $3(15 \%)$ \\
\hline Black peper & Piper nigrum $\mathrm{L}$. & $3(15 \%)$ \\
\hline Others ${ }^{* * *}$ & - & $2(10 \%)$ \\
\hline
\end{tabular}

* Values in parentheses refer to the percentage of farmers who mentioned the species in the interview; ${ }^{*}$ feijão-de-porco (Canavalia esiformes (L.) DC);e Pigeon Pea (Cajanus cajan (L.) Millsp); ${ }^{* * *}$ Sweet Potato (Ipomoea batatas (L.) Lam), peanut (Arachis hypogaea L.) and Cowpea beans (Vigna unguiculata (L.) Walp). 
Table 3. Tree species suggested by interviewees for the composition of agroforestry systems for recovery of Legal Reserves.

\begin{tabular}{|c|c|c|}
\hline Common name & Scientific Name & Number of respondents * \\
\hline Cashew & Anacardium occidentale L. & $12(60 \%)$ \\
\hline Mango & Mangifera indica $\mathrm{L}$. & $11(55 \%)$ \\
\hline Yellow mombin & Spondias mombin $\mathrm{L}$. & $7(35 \%)$ \\
\hline Mountain Apple & Syzygium jambos (Lam.) DC. & $6(30 \%)$ \\
\hline Achiote & Bixa orellana $\mathrm{L}$. & $6(30 \%)$ \\
\hline Brazilian peppertree & Schinus terebinthifolius Raddi & $5(25 \%)$ \\
\hline Jackfruit & Artocarpus heterophyllus Lam. & $4(20 \%)$ \\
\hline Catbrier & Smilax lutescens Vell. & $4(20 \%)$ \\
\hline Brazilian guava & Psidium araca Raddi & $3(15 \%)$ \\
\hline Mangaba & Hancornia speciosa var. speciosa Gomes & $3(15 \%)$ \\
\hline Avocado & Persea americana Miller & $2(10 \%)$ \\
\hline Barbados cherry & Malpighia emarginata DC. & $2(10 \%)$ \\
\hline Coconut & Cocos nucifera $\mathrm{L}$. & $2(10 \%)$ \\
\hline Jocote & Spondias purpurea $\mathrm{L}$. & $2(10 \%)$ \\
\hline Others $^{* *}$ & - & $1(5 \%)$ \\
\hline
\end{tabular}

* Values in parentheses refer to the percentage of farmers who mentioned the species in the interview; ${ }^{* \star}$ Others: tree sorrel (Averrhoa bilimbi L.), starfruit (Averrhoa carambola L.), sabiá (Mimosa caesalpiniaefolia Benth), sugar-apple (Annona squamosa L.) e cocoa (Theobroma cacao L.).

Most interviewed farmers have shown interest in Agroforestry Systems and its adoption for the recovery of the Legal Reserves, within the context of the Territorial Rural Development Program (PDRT) of Fibria. However, the company must develop extension projects with the community, aiming to inform the farmers about implantation techniques and management of Agroforestry Systems to maximize the scope of its possible benefits for recomposing its areas, even if the company has other LRs areas.

It was also possible to identify agricultural and tree species of interest to farmers for the composition of Agroforestry Systems, considering suggestions from the community, environmental legislation, and the list of species adopted in the Fibria Environmental Restoration Program. The most indicated agricultural species by the community coincide with the ones most cultivated today, which have adapted to the climatic conditions of the region. In this regard, it is suggested that the "target species" should be chosen based on the identification of regional commercial demands such as pepper and cashew - to obtain a scale of production that could favor their commercialization. It is important to emphasize that one should not standardize or choose an Agroforestry System model to follow, as each family should have the autonomy to adapt it to their conditions, culture, and available workforce.

\section{Acknowledgements}

We thank Fibria Celulose S.A. for the financial support and for providing the data.

\section{Submission status}

Received: 16 Mar. 2017

Accepted: 11 July 2018

Associate editor: Vanessa Maria Basso (10 0000-0003-3141-2262

\section{Correspondence to}

\section{Bruna Paolinelli Reis}

Universidade Federal de Viçosa (UFV), Departamento de Engenharia Florestal, Av. P. H. Holfs, s/n, CEP 36570-000, Viçosa, MG, Brasil e-mail: brunapaolinelli@gmail.com

\section{Financial support}

Fibria Celulose S.A.

\section{References}

Albuquerque UP, Alves A, Silva A, Silva V. Atualidades em etnobiologia e etnoecologia. Recife: Sociedade Brasileira de Etnobiologia e Etnoecologia; 2002.

Araujo DSD, Pereira OJ, Peixoto AL. Campos nativos at the Linhares Forest Reserve, Espírito Santo, Brazil. In: Thomas W, editor. The 
Atlantic Coastal Forest of Northeastern Brazil. New York: The New York Botanical Garden; 2008. p. 365-388.

Brasil. Ministério do Meio Ambiente. Instrução Normativa n. 5, de 8 de setembro de 2009. Dispõe sobre os procedimentos metodológicos para restauração e recuperação de Áreas de Preservação Permanente e de reserva legal instituídas pela Lei $\mathrm{n}^{\circ} 4.771$, de 15 de setembro de 1965. Diário Oficial da União, Brasília, DF (2009 Sept. 9); Sec. 1: 65-66.

Brasil. Lei n. 12.651, de 25 de maio de 2012. Dispõe sobre o novo código florestal. Diário Oficial da União, Brasília, DF (2012 May 25).

Fibria Celulose. Relatório de sustentabilidade 2010. 2010 [cited 2014 Nov. 25]. Available from: https://bit.ly/2TojZtq

Gil AC. Métodos e técnicas de pesquisa social. 6th ed. São Paulo: Atlas; 2008.

Instituto Capixaba de Pesquisa, Assistência Técnica e Extensão Rural - Incaper. Programa de assistência técnica e extensão rural: Proater 2011-2013. 2011 [cited 2015 Mar. 22]. Available from: https://bit.ly/2KGeYZx

Martins SV, Sartori M, Raposo Filho FL, Simoneli M, Dadalto G, Pereira ML et al. Potencial de regeneração natural de florestas nativas nas diferentes regiões do estado do Espírito Santo. Vitória: Cedagro; 2014.

Martins TP, Ranieri VEL. Agroforestry as an alternative to legal reserves. Ambiente \& Sociedade 2014; 17(3): 79-9. 10.1590/ S1414-753X2014000300006

Mazzon JÁ, Kamakura WA. Estratificação socioeconômica e consumo no Brasil. São Paulo: Blucher; 2013.

Navas R, Silva RJ. Ecological restoration indicators in agroforestry systems in the Atlantic forest. Ciência e Natura 2016; 38(2): 656-664. 10.5902/2179460X19666
Nóbrega NEF, Silva JGF, Ramos HE, Pagung FS. Balanço hídrico climatológico e classificação climática de Thornthwaite e Koppen para o município de São Mateus-ES. In: XVIII Congresso Nacional de Irrigação e Drenagem; 2008; São Mateus. São Mateus: Abid; 2008 [cited 2015 Apr. 21]. p. 1-6. Available from: https://bit. ly/2MWifGF

Oliveira Neto SN, Lana VM, Costa CB, Viana MCM. Sistemas agroflorestais para adequação ambiental de propriedades rurais. Informe Agropecuário 2012; 33(271): 70-77.

Quinteiro MMC, Lazos-Ruíz A, Alexandre BR, Magalhães LM. Conocimiento etnoagrícola al borde de la desaparición: el caso de una comunidad de la Mata Atlántica brasileña. Cuadernos de Biodiversidad 2016; 51: 15-28. 10.14198/cdbio.2016.51.03

Rodrigues ER, Cullen L Jr, Beltrame TP, Moscogliato A, Silva ICD. Avaliação econômica de sistemas agroflorestais implantados para recuperação de reserva legal no Pontal do Paranapanema, São Paulo. Revista Árvore 2007; 31(5): 941-948. 10.1590/S010067622007000500018

Saporetti AW Jr, Schaefer CEGR, Souza AL, Soares MP, Araújo DSD, Meira-Neto JAA. Influence of soil physical properties on plants of Mussununga ecosystem, Brazil. Folia Geobotaniaca 2012; 47(1): 29-39. 10.1007/s12224-011-9106-9

Tuan YF. Topofilia: um estudo da percepção, atitudes e valores do meio ambiente. São Paulo: Difel; 1980.

Vieira DL, Holl KD, Peneireiro FM. Agro-successional restoration as a strategy to facilitate tropical forest recovery. Restoration Ecology 2009; 17(4): 451-459. 10.1111/j.1526-100X.2009.00570.x 